\title{
SEASON AND SEX OF HOST AFFECT INTENSITIES OF ECTOPARASITES IN WESTERN FENCE LIZARDS (SCELOPORUS OCCIDENTALIS) ON THE CENTRAL COAST OF CALIFORNIA
}

\author{
Anthony S. Lumbad, Larisa K. Vredevoe, and Emily N. Taylor* \\ Department of Biological Sciences, California Polytechnic State University, San Luis Obispo, CA 93407-0401 \\ *Correspondent: etaylor@calpoly.edu
}

\begin{abstract}
Seasonal variability in intensities of ectoparasites of western fence lizards (Sceloporus occidentalis) was quantified in spring, summer, and autumn 2008. Lizards were suspended over pans of water in the laboratory to enumerate replete western black-legged ticks (Ixodes pacificus) and mites. Intensity of ectoparasites was greatest in spring. On average, mites comprised the greatest proportion of ectoparasites, followed by larval and nymphal ticks, respectively. Mites were on lizards year-round. Overall intensity of ticks was greatest in spring, but low during summer and autumn. Males were more heavily parasitized by ticks than females in spring, whereas females had greater intensities of mites in autumn. There was a slight, positive relationship between size of lizard and intensity of ticks, but not with intensity of mites. We report greater intensities of ectoparasites on $S$. occidentalis than several other studies, which may be due to differences in habitats and methods.
\end{abstract}

Resumen-La variabilidad estacional en la intensidad de ectoparásitos de la lagartija (Sceloporus occidentalis) fue cuantificada en la primavera, el verano y el otoño del 2008. Para contar el número de garrapatas de patas negras (Ixodes pacificus) y de ácaros en el laboratorio, las lagartijas fueron suspendidas sobre cazuelas de agua. La intensidad de ectoparásitos fue mayor durante la primavera. Los ácaros constituyeron la mayor porción de ectoparásitos, seguidos por larvas y ninfas de garrapatas, respectivamente. En las lagartijas los ácaros se encontraron presentes durante todo el año. En general la intensidad de garrapatas fue mayor en la primavera, pero baja durante el verano y el otoño. Los machos fueron más severamente parasitados por garrapatas que las hembras durante la primavera, mientras que las hembras tuvieron una mayor intensidad de ácaros en el otoño. Se encontró una ligera relación positiva entre el tamaño de la lagartija y la intensidad de garrapatas, pero no con la intensidad de ácaros. Reportamos una mayor intensidad de ectoparásitos en S. occidentalis que en varios otros estudios, lo cual se puede atribuir a diferencias de hábitat y metodología.

Because male and female hosts may exhibit differences in condition, immune response, and hormonal profiles, sex of host is an important attribute that may affect intensities of parasites (number of parasites per host). Male hosts usually have greater intensities of ectoparasites than female hosts (Zuk, 1990; Zuk and McKean, 1996; Roberts et al., 2004), with few studies showing females more heavily parasitized than males (e.g., Christe et al., 2007). Androgens have been implicated as mediators of differences in parasitism between sexes because of their negative effects on immune response (Wedekind and Folstad, 1994; Mougeot et al., 2006). The immunocompetence-handicap hypothesis suggests that androgen-dependent characters of males indicate quality of mate, quality of rival, or both, because suppression of immunity associated with elevated androgens imposes a variety of costs on the male (Folstad and Karter, 1992). Hormones of hosts can influence success of parasites directly or act indirectly via the immune system of the host (Beckage, 1993). Additionally, many parasites secrete hormones, neuropeptides, or cytokine-like molecules that influence physiological and immunological responses of vertebrate hosts (Wikel, 1996), and parasites can secrete factors that modify concentrations of hormones in the host.

The effect of sex of host on intensities of parasites has been well-studied in lizards. Male lizards typically experience greater intensities of ectoparasites than do females (Tälleklint-Eisen and Eisen, 1999; Schall et al., 2000; Eisen et al., 2001; Amo et al., 2005), and the effect of sex of host is mediated via testosterone (Salvador et al., 
1996; Olsson et al., 2000; Klukowski and Nelson, 2001; Cox and John-Alder, 2007). It is possible that testosterone leads to increased parasitism via direct suppression of the immune response, indirectly by altering expenditure of energy by hosts, or by stimulating males to make more frequent or lengthy movements; thereby, increasing exposure to host-seeking parasites (Veiga et al., 1998; Hughes and Randolph, 2001; Belliure et al., 2004).

The western fence lizard (Sceloporus occidentalis) and western black-legged tick (Ixodes pacificus) have been well-studied in California. Subadult life stages (larvae and nymphs) of $I$. pacificus infest S. occidentalis (Lane and Loye, 1989; Lane et al., 1995; Tälleklint-Eisen and Eisen, 1999; Schall et al., 2000), southern alligator lizards (Elgaria multicarinata; Wright et al., 1998), and several other species of lizards, as well as avian and rodent hosts (Holdenreid et al., 1951; Lane and Loye, 1991; Brown and Lane, 1996; Peavey et al., 1997; Eisen et al., 2004a; Lane et al., 2005; Castro and Wright, 2007). Adult $I$. pacificus feed primarily on mammals (Castro and Wright, 2007). In California, I. pacificus transmits Borrelia burgdorferi sensu stricto, the spirochete responsible for Lyme disease in humans (Burgdorfer et al., 1985; Manweiler et al., 1992) and Anaplasma phagocytophilum, the rickettsial agent of granulocytic anaplasmosis in humans, horses, and dogs (Madigan, 1993; Dumler et al., 1995; Grieg et al., 1996; Reubel et al., 1998). Lizards are infrequent reservoirs for Borrelia in the United States, and some species may reduce prevalence of infection by B. burgdorferi sensu stricto in populations of ticks (Manweiler et al., 1992; Wright et al., 1998; Kuo et al., 2000; Casher et al., 2002; Giery and Ostfield, 2007). In California, S. occidentalis and E. multicarinata are reservoir-incompetent hosts for $B$. burgdorferi (Manweiler et al., 1992; Wright et al., 1998); host complement-mediated borreliacidal factors in S. occidentalis reportedly eliminate spirochetes in both tick and host (Lane and Quistad, 1998; Kuo et al., 2000), and similar barriers may exist in other apparently reservoir-incompetent lizards in the eastern United States, such as five-lined skinks (Plestiodon fasciatus; Giery and Ostfield, 2007).

Lizards may play a role in reducing local prevalence of $B$. burgdorferi because infected nymphs that feed on lizards instead of rodents will fail to transmit the spirochete (Tälleklint-
Eisen and Eisen, 1999; Eisen et al., 2001). In some habitats in Mendocino County, California, lizards have higher intensities of I. pacificus than rodents (Eisen et al., 2004b), suggesting that abundance of lizards and the propensity of ticks to attach to reservoir-incompetent hosts are important in reducing local prevalence of infected ticks. As a result of this relationship between I. pacificus and S. occidentalis in mediating the ecology of B. burgdorferi, it is important to understand spatial and temporal trends in infestations of ticks on lizards, as well as how attributes of hosts affect parasitism.

Several studies have examined the effect of abiotic and biotic factors on intensities of ectoparasites on $S$. occidentalis in California. These studies determined that lizards are heavily infested with larval and nymphal I. pacificus in some regions, that rates of infestations and intensities of ticks vary seasonally and annually (Eisen et al., 2001), that intensity of ticks varies according to habitat, and that adult male lizards usually are more heavily parasitized than adult females (Tälleklint-Eisen and Eisen, 1999; Schall et al., 2000; Eisen et al., 2001). In each of these studies, intensity of ticks was quantified by visual inspection, by removing ticks using forceps, or both. Although these methods are useful to quantify engorged ticks, newly attached larval ticks could be missed easily because they are small enough to hide under scales on lizards. Furthermore, only one of these studies (Schall et al., 2000) simultaneously quantified infestations of ticks and mites. Finally, although other sites were surveyed in one study (Schall et al., 2000), the remaining studies focused on populations of lizards and ticks in Mendocino County, California. It is important to examine host-parasite dynamics in other regions where the two species are common to more fully understand the myriad of factors affecting intensity of ectoparasites and its effect on health of host.

We examined effects of season and sex of host on intensities of ticks and mites in coastal central California to understand regional dynamics of infestations of ectoparasites on Sceloporus. We hypothesized that intensity of ectoparasites would be affected by sex of host and season, with peak levels occurring in males in spring. Intensity of ectoparasites was expected to be greatest in males in spring when they have high concentrations of testosterone, peak reproductive effort, and maximal exposure to questing 
ticks due to increased size of territories and movements. To test this hypothesis, we used a sampling protocol designed to allow more accurate quantification of ticks than previous studies by collecting replete ectoparasites of lizards, particularly ticks, as they fell off the host following engorgement.

Materials and Methods-The study was conducted in Poly Canyon on the campus of California Polytechnic State University in the foothills of the Santa Lucia Mountains, San Luis Obispo County, California $\left(35.3^{\circ} \mathrm{N}, 120.7^{\circ} \mathrm{W}\right)$. Habitat consisted of oak (Quercus) woodland with several riparian areas and heavily grazed pastures. Lizards were captured by hand-held noose from rocks, oak trees, and, occasionally, from wood fences. To examine seasonality of infestations of ectoparasites on $S$. occidentalis, we collected lizards in spring (13-16 April), summer (12 July), and autumn (29 September) 2008. In each of these seasons, 7-8 male and 7-8 female lizards were collected (all were $>60 \mathrm{~mm}$ in snout-vent length). Lizards were placed individually in cloth bags and transported to the laboratory where they were weighed $( \pm 0.5 \mathrm{~g})$, measured (snout-vent length $\pm 0.5 \mathrm{~mm}$ ), and placed in wire-mesh cages (20 by 8 by $7.5 \mathrm{~cm}$ ). Bags were inspected for mites and ticks and no parasite dropped off in bags. At termination of the experiment, lizards were toe-clipped to avoid recapture later in the year and returned to their site of capture.

To quantify natural intensities of ectoparasites of lizards, animals were housed individually in wire-mesh cages suspended above 33 by 21.5 by $6.5-\mathrm{cm}$, enamel, dissecting pans that were filled with water so that any parasite dropping off lizards would fall into the pans for collection. Pans were placed in environmental chambers $\left(27^{\circ} \mathrm{C}, 8 \mathrm{~L}: 16 \mathrm{D}\right)$ until all ectoparasites were recovered. Crickets were provided to lizards daily and water was provided ad libitum. Ticks and mites were collected from the water daily using a fine-tipped paintbrush and species and life stages of ticks (larva or nymph) were recorded. Representative juvenile ticks were identified as I. pacificus by use of a taxonomic key (Durdan and Keirans, 1996); thereafter, we assumed all ticks were $I$. pacificus because previous studies have confirmed that this is typically the only species of tick that infests S. occidentalis in California (Tälleklint-Eisen and Eisen, 1999; Casher et al., 2002; Eisen et al., $2004 a)$. Species of mites were not identified. After 2 weeks, all ticks had fed to repletion and fallen from lizards, but some mites remained on lizards because mites do not necessarily leave hosts once they are replete. At this time, lizards were examined carefully by hand and all visible mites were removed with forceps and quantified. Although it is possible to miss some mites in this way, visual examination may reasonably identify $>90 \%$ of mites (Schall et al., 2000).

We performed all data analyses using Minitab version 15 (Minitab, Inc., State College, Pennsylvania). Because intensities of parasites were not distributed normally, they exhibited extreme heterogeneity of variance among seasons and between sexes, and they often included outliers, we used nonparametric statistics to compare median intensities of parasites. We analyzed five measures of intensities of parasites: total number of ectoparasites (ticks and mites), total number of ticks, total number of mites, number of larval ticks, and number of nymphal ticks. We used Mood's median tests to analyze intensity of parasites by season (with sexes pooled) because this test is robust against outliers. Mann-Whitney tests were used to compare intensities of parasites of each sex within each season. Pearson's correlations were used to examine relationships between larval and nymphal intensities, and between intensities of ticks and mites. We used linearregression analysis to examine relationships between size (snout-vent length of lizard) and intensities of parasites.

Results-There was a strong effect of season on all measures of intensities of parasites, with greater parasitic loads on lizards in spring than in summer or autumn (total number of ticks: $\chi^{2}$ $=22.88, P<0.001$; total number of mites: $\chi^{2}=$ 12.07, $P=0.002$; number of larval ticks: $\chi^{2}=$ 25.37, $P<0.001$; number of nymphal ticks: $\chi^{2}=$ 25.37, $P<0.001$; Fig. 1). Male S. occidentalis had greater intensities of ticks in spring than females (total number of ticks: $W=100.0, P<0.001$; number of larval ticks: $W=100.0, P<0.001$; number of nymphal ticks: $W=95.0, P=0.005$; Fig. 1a). However, in summer and autumn, median intensities of ticks for males and females were each zero (range $=0-2$ ); thus, there was no significant difference in intensity between sexes. Examining intensities of parasites by life stage of ticks yielded the same results, with males having greater intensities than females only in spring for each life stage (number of larval ticks: $W=$ 100.0, $P<0.001$; number of nymphal ticks: $W=$ $95, P=0.005)$. For mites, female $S$. occidentalis had greater intensities than males in autumn ( $W$ $=38.5, P=0.048)$, the season when median intensities of mites were lowest; however, there was no difference in intensities between sexes in spring or summer (spring: $W=61, P=0.494$; summer: $W=54, P=0.862$; Fig. $1 \mathrm{~b})$.

Analyses of factors relating to intensities of ticks were performed only for spring because median intensities of ticks in summer and autumn were zero. Intensity of larval ticks was correlated positively with intensity of nymphal ticks $(r=0.908, P<0.001)$, and intensity of larval ticks averaged 2.6 times intensity of nymphal ticks (range $=0.14-8$; Fig. 2a). There was no significant relationship between total numbers of ticks and mites $(r=-0.42, P=0.11$; Fig. 2b). In spring, snout-vent length was positively associated with intensities of ticks, whether 

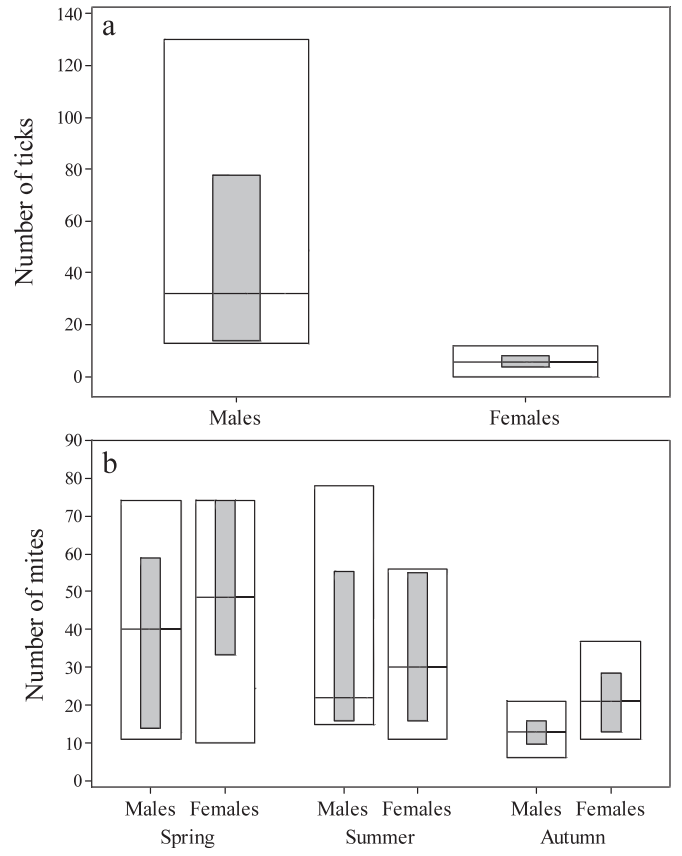

FIG. 1-Median numbers of a) larvae and nymphs of the tick Ixodes pacificus in spring and b) mites in spring, summer, and autumn 2008 on male and female western fence lizards Sceloporus occidentalis on the central coast of California. Horizontal bars are the median, gray boxes are $95 \%$ confidence limits about the median, and white boxes are minimum and maximum numbers of parasites.

quantified as total number of ticks $\left(r^{2}=0.232, P\right.$ $=0.034)$, number of larval ticks $\left(r^{2}=0.222, P=\right.$ $0.037)$, or number of nymphal ticks $\left(r^{2}=0.222\right.$, $P=0.037)$. Therefore, snout-vent length of lizards accounted for ca. $22 \%$ of the variation in intensities of ticks. Male lizards were slightly larger in snout-vent length than females (males, $n=22,67.9 \pm 0.7 \mathrm{~mm}$; females, $n=24,65.0 \pm$ $0.6 \mathrm{~mm}$; 2-sample Students $t$-test $=3.19, P=$ $0.003)$. When sexes were examined separately, there was no relationship between snout-vent length and intensities of ticks in spring for males $\left(r^{2}=0.000 ; P=0.380\right)$ or females $\left(r^{2}=0.000\right.$; $P=0.520)$. Snout-vent length did not affect intensities of mites $\left(r^{2}=0.000 ; P=0.560\right)$.

Discussion-We observed a strong effect of season on intensities of ectoparasites of $S$. occidentalis. Parasitic loads were highest in spring for both ticks (larvae and nymphs of I. pacificus) and mites. Median intensities of ticks dropped to zero in summer and autumn for both sexes, with
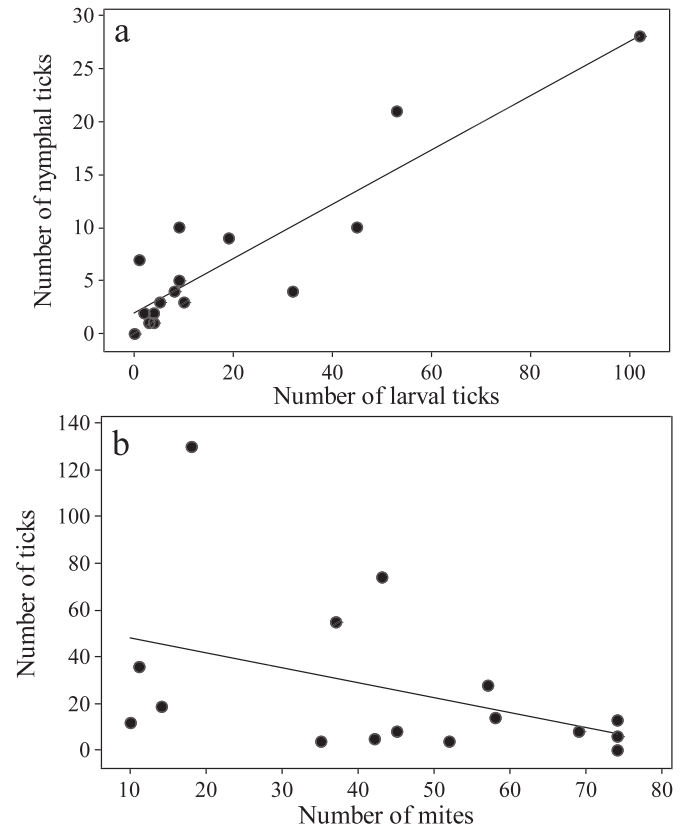

FIG. 2-Relationships between a) number of larvae and nymphs of the tick Ixodes pacificus $(r=0.908, P<$ $0.001)$ and b) number of mites and ticks $(r=-0.42$, $P=0.110$ ) infesting western fence lizards Sceloporus occidentalis on the central coast of California in spring 2008.

maximum intensities of ticks observed at only 3 compared to 130 ticks in spring. Intensities of mites also decreased during spring-autumn, but mites were present on lizards in all three seasons. One reason for abundance of ectoparasites on lizards in spring was that more subadult ticks and mites are in the environment at certain times of year due to seasonality of their life cycles (Jameson, 1972; Eisen et al., 2001, 2002, 2004b; Padgett and Lane, 2001; Klukowski, 2004). Both pterygosomatid and trombiculid mites, which may parasitize $S$. occidentalis, feed on the host for days to weeks before molting to the next life stage, but other aspects of their life histories differ. Chiggers are only parasitic as larvae, feeding on lymph and fluids in tissues, but not blood of the host; then they drop off the host to continue development in the environment (Goldberg and Bursey, 1991, 1993). Geckobiella is parasitic during all life stages and remains on the host, except for replete females that leave the host to oviposit (Goodwin, 1954). Our results resemble those of Eisen et al. (2001) and Lane and Loye (1989), who reported that peak 
intensities of ticks occurred in spring in $S$. occidentalis in northern California, and that intensities declined dramatically in summer and autumn. Schall et al. (2000) studied one northern population and two southern populations in California and reported similar results for intensities of ticks but determined that intensities of mites peaked in summer (late June). In our study, intensities of mites peaked in spring. The positive correlation between intensities of mites and ticks, which both peaked in spring, resulted in highest total intensities of parasites during this season. This overlap suggests that competition between ticks and mites for resources provided by hosts may not be particularly intense, permitting seasonal co-occurrence on hosts. Schall et al. (2000) noted that ticks, but not mites, congregated in nuchal pockets of hosts, which may prevent significant competition for resources provided by hosts. Habitat may also strongly affect co-occurrence of mites and ticks on hosts (Jameson and Brennan, 1957; Eisen et al., 2004).

In general, our study detected greater intensities of ticks on S. occidentalis than other studies. Although Tälleklint-Eisen and Eisen (1999) counted only nymphs in their study and, therefore, had lower intensities of ticks than our study, Eisen et al. (2001) and Schall et al. (2000) counted larvae and nymphs. Average larva:nymph ratio on lizards in our study was 1:2.6; another study reported this ratio as 1:0.8 in 1999 and 1:2.4 in 2000 (Eisen et al., 2001). The difference in intensities of ectoparasites among studies could be due partially to inherent differences in field sites in terms of vegetation, humidity, temperature, and other factors that affect abundance of ticks (Slowik and Lane, 2001; Eisen et al., 2004b). Results also can vary annually (Eisen et al., 2001), again presumably related to differences in abundance of questing ticks in the environment. Alternatively, differences in intensities of parasites between our study and other studies may result from differences in methods. When larvae of $I$. pacificus first attach to lizards, they are almost undetectable and many may hide partially or completely underneath the scales of hosts. Accurate quantification of larvae, even with magnification, may not be possible until several days after attachment. Collecting ectoparasites as they fall from hosts in the laboratory is a better way of determining intensities of ectoparasites. For example, Goldberg and Bursey (1991) determined duration of feeding and intensities of ticks and mites on lizards by quantifying ectoparasites as they fell off hosts held in beakers. Eisen et al. (2004b) counted larval and nymphal I. pacificus on rodents in the field and brought the rodents into the laboratory to determine accuracy of field inspection by allowing any undetected ticks to drop off hosts. As expected, they reported that nymphal ticks were detected easily in the field, but detection of larval ticks was only ca. $73 \%$. Our approach, where we allowed ticks to feed to repletion on hosts, permitted accurate quantification of intensities of ticks and may explain why our study had a higher larva:nymph ratio than Eisen et al. (2001).

Quantification of mites from lizards poses an additional challenge because, although all $I$. pacificus drop off shortly after repletion and can be quantified easily, mites may remain on lizards for highly variable times during and after feeding (Goldberg and Bursey, 1991, 1993). Thus, our calculations of intensities of mites on lizards, which relied on visual inspection of hosts in addition to counts of those that dropped from hosts, are probably an underestimate of true intensities. Oak woodlands and riparian habitats in conjunction with mild temperatures on the central coast of California may be more permissive to year-round infestation of $S$. occidentalis by mites, rather than more seasonal infestations as observed in northern California (Schall et al., 2000).

We observed a strong difference between sexes in intensities of ectoparasites of S. occidentalis, as well as a weak effect of size (snout-vent length). In general, larger lizards sustained heavier intensities of ectoparasites. Male lizards in our study had higher intensities of ticks in spring than females, which may be slightly confounded by sexual dimorphism in size of lizards because males were slightly larger than females. Higher intensities of ectoparasites on males relative to females has been reported previously for $S$. occidentalis (Tälleklint-Eisen and Eisen, 1999; Schall et al., 2000; Eisen et al., 2001) and also has been observed in striped plateau lizards $S$. virgatus (Cox and John-Alder, 2007), eastern fence lizards $S$. undulatus (Klukowski and Nelson, 2001), sand lizards Lacerta agilis (Olsson et al., 2000), wall lizards Podarcis muralis (Oppliger at al., 2004; Amo et al., 2005), and large psammodromus lizards Psammodromus algirus (Veiga et al., 1998). Indeed, most studies report higher 
intensities of ectoparasites on males relative to females among vertebrate hosts (Zuk, 1990; Zuk and McKean, 1996; Schalk and Forbes, 1997; Hughes and Randolph, 2001; Klein, 2004; Roberts et al., 2004). This may represent preference by parasites for hosts that are male over those that are female, sex-specific use of habitat and social aggregation (Zuk and McKean, 1996), inhibition of immune responses to parasites by androgens of males (Folstad and Karter, 1992; Veiga et al., 1998; Belliure et al., 2004), or higher exposure of males to parasites via androgen-induced stimulation of movement and territorial patrolling (Marler et al., 1995; Cox et al., 2005).

Our results indicate that mites and ticks clearly have independent patterns of infestation on $S$. occidentalis. Intensities of mites peaked in spring, decreased during summer, and were lowest in autumn. This may reflect greater abundance of mites in the environment in spring. Klukowski (2004) determined that abundance of mites in Tennessee peaked in summer and was accompanied by peak intensities of mites on eastern fence lizards ( $S$. undulatus) in summer. Interestingly, Schall et al. (2000) observed peak intensities of mites in summer in a population of $S$. occidentalis in northern California. In their study and ours, the fact that ticks infested lizards mainly in spring and mites were present on lizards yearround and in greater numbers than subadult ticks reflects an important difference in the biology of ticks and mites. Mites may remain on hosts for variable and sometimes extended periods of time, whereas three-host species of ticks, such as I. pacificus, leave the host when replete, molt, and then seek the next host. Three-host ticks spend a large proportion of their lives off the host in the environment, completing a life cycle that may span $\geq 2$ years in contrast to reptile-infesting mites, which may reside continuously on their hosts and have shorter life spans (Goodwin, 1954; Yuval and Spielman, 1990; Goldberg and Bursey, 1991, 1993; Padgett and Lane, 2001). Whereas male lizards harbored more ticks than female lizards during spring, females were more heavily parasitized by mites than males in autumn. The reason for this difference between sexes in abundance of mites is unknown. As stated above, most studies have shown that male lizards have greater intensities of ectoparasites than females (Goldberg and Bursey, 1991; Veiga et al., 1998;
Tälleklint-Eisen and Eisen, 1999; Olsson et al., 2000; Schall et al., 2000; Eisen et al., 2001; Klukowski and Nelson, 2001; Oppliger et al., 2004; Amo et al., 2005; Cox and John-Alder, 2007). No difference between sexes in intensities of mites was reported for S. undulatus (Klukowski, 2004), S. occidentalis (Schall et al., 2000), or collared lizards (Crotaphytus collaris; Curtis and Baird, 2008). In contrast, male striped plateau lizards ( $S$. virgatus) harbor more mites than females during the breeding season in spring (Cox and John-Alder, 2007).

We have determined that $S$. occidentalis on the central coast of California have the greatest intensities of ectoparasites in spring. Mites were present on lizards year-round, while ticks were on lizards mainly in spring. Male lizards were more heavily parasitized by ticks than females in spring, whereas females had greater intensities of mites than males in autumn. Quantifying seasonal intensities of pathogen-transmitting parasites including ticks and mites is essential in understanding dynamics of the ecology of pathogens in a population. In particular, we generally detected greater intensities of ectoparasites than most other studies in California. Our results support previous studies that demonstrated that $S$. occidentalis serve as hosts for these ectoparasites in riparian and oak-woodland habitats, which may be informative in understanding transmission of $B$. burgdorferi in this region. Indeed, subadult $I$. pacificus, especially nymphs, more frequently infest $S$. occidentalis rather than rodents (Casher et al., 2002). If ticks preferentially feed on B. burgdorferi-incompetent lizards in such habitats, this would be expected to lower the incidence of infection in rodents. Further studies are necessary to elucidate the relative importance of reptiles, birds, and rodents as hosts in maintenance of subadult ticks in this region of California.

We thank A. Branske, B. Capper, K. James, K. Tallon, and B. Weinberger for help collecting lizards in the field, caring for them in the laboratory, or both. Assistance with translation of the abstract to Spanish was provided by G. Avina and I. Blandon. C. Montgomery provided comments on an early version of the manuscript.

\section{Literature Cited}

Amo, L., P. Lopez, and J. Martin. 2005. Prevalence and intensity of haemogregarine blood parasites and 
their mite vectors in the common wall lizard, Podarcis muralis. Parasitology Research 96:378-381.

Beckage, N. E. 1993. Endocrine and neuroendocrine host-parasite relationships. Receptor 3:233-245.

Belliure, J., L. Smith, and G. Sorci. 2004. Effect of testosterone on $\mathrm{T}$ cell-mediated immunity in two species of Mediterranean lacertid lizards. Journal of Experimental Zoology A, Comparative Experimental Biology 301:411-418.

Brown, R. N., AND R. S. Lane. 1996. Reservoir competence of four chaparral-dwelling rodents for Borrelia burgdorferi in California. American Journal of Tropical Medicine and Hygiene 54:84-91.

Burgdorfer, W., R. S. Lane, A. G. Barbour, R. A. Gresbrink, And J. R. Anderson. 1985. The western blacklegged tick, Ixodes pacificus: a vector of Borrelia burgdorferi. American Journal of Tropical Medicine and Hygiene 34:925-930.

Casher, L., R. S. Lane, R. Barrett, and L. Eisen. 2002. Relative importance of lizards and mammals as hosts for ixodid ticks in northern California. Experimental and Applied Acarology 26:27-143.

Castro, M. B., and S. A. Wright. 2007. Vertebrate hosts of Ixodes pacificus (Acari: Ixodidae) in California. Journal of Vector Ecology 32:140-149.

Christe, P., O. Glaizot, G. Evanno, N. Bruyndonckx, G. Devevey, G. Yannic, P. Patthey, A. Maeder, P. Vogel, AND R. ARlettaz. 2007. Host sex and ectoparasites choice: preference for and higher survival on female hosts. Journal of Animal Ecology 76:703-10.

Cox, R. M., ANd H. B. John-Alder. 2007. Increased mite parasitism as a cost of testosterone in male striped plateau lizards, Sceloporus virgatus. Functional Ecology 21:327-334.

Cox, R. M., S. L. Skelly, and H. B. John-Alder. 2005. Testosterone inhibits growth of juvenile male eastern fence lizards (Sceloporus undulatus): implications for energy allocation and sexual size dimorphism. Physiological and Biochemical Zoology 78:531-545.

Curtis, J. L., And T. A. Baird. 2008. Within-population variation in free-living adult and ectoparasitic trombiculid mites on collared lizards. Herpetologica 64:189-199.

Dumler, J. S., K. M. Asanovich, J. S. Bakken, P. Richter, R. Kimsey, and J. E. Madigan. 1995. Serologic crossreactions among Ehrlichia equi, Ehrlichia phagocytophila, and human granulocytic ehrlichia. Journal of Clinical Microbiology 33:1098-1103.

Eisen, R. J., L. Eisen, and R. S. Lane. 2001. Prevalence and abundance of Ixodes pacificus immatures (Acari: Ixodidae) infesting western fence lizards (Sceloporus occidentalis) in northern California: temporal trends and environmental correlates. Journal of Parasitology 87:1301-1307.

Eisen, L., R. J. Eisen, and R. S. Lane. 2002. Seasonal activity patterns of Ixodes pacificus nymphs in relation to climatic conditions. Medical and Veterinary Entomology 16:235-244.
Eisen, L., R. J. Eisen, and R. S. Lane. 2004a. The roles of birds, lizards, and rodents as hosts for the western black-legged tick Ixodes pacificus. Journal of Vector Ecology 29:295-308.

Eisen, R. J., L. Eisen, and R. S. Lane. 2004b. Habitatrelated variation in infestation of lizards and rodents with Ixodes ticks in dense woodlands in Mendocino County, California. Experimental and Applied Acarology 33:215-233.

Folstad, I., AND A. Karter. 1992. Parasites, bright males, and the immunocompetence handicap. American Naturalist 139:603-622.

Giery, S. T., AND R. S. Ostfield. 2007. The role of lizards in the ecology of Lyme disease in two endemic zones of the northeastern United States. Journal of Parasitology 93:511-517.

GoldberG, S. R., and C. R. Bursey. 1991. Duration of attachment by mites and ticks on the iguanid lizards Sceloporus graciosis and Uta stansburiana. Journal of Wildlife Diseases 27:719-722.

Goldberg, S. R., And C. R. Bursey. 1993. Duration of attachment of the chigger, Eutrombicula lipovskyana (Trombiculidae) in mite pockets of Yarrow's spiny lizard, Sceloporus jarrovii (Phrynosomatidae) from Arizona. Journal of Wildlife Diseases 29:142-144.

Goodwin, M. H. 1954. Observations on the biology of the lizard mite Geckobiella texana (Banks) 1904 (Acarina: Pterygosomidae). Journal of Parasitology 40:54-59.

Greig, B., K. M. Asanovich, P. J. Armstrong, and J. S. Dumler. 1996. Geographic, clinical, serologic, and molecular evidence of granulocytic ehrlichiosis, a likely zoonotic disease, in Minnesota and Wisconsin dogs. Journal of Clinical Microbiology 34:44-48.

Holdenreid, R., F. C. Evans, and D. S. Longanecker. 1951. Host-parasite-disease relationships in a mammalian community in the central coast range of California. Ecological Monographs 21:1-18.

Hughes, V. L., and S. E. Randolph. 2001. Testosterone depresses innate and acquired resistance to ticks in natural rodent hosts: a force for aggregated distributions of parasites. Journal of Parasitology 87:49-54.

Jameson, E. W. 1972. Temperature-development relations of Eutrombicula belkini (Acarina: Trombiculidae) and their possible ecological significance. Journal of Parasitology 58:343-347.

Jameson, E. W., and J. M. Brennan. 1957. An environmental analysis of some ectoparasites of small forest mammals in the Sierra Nevada, California. Ecological Monographs 27:45-54.

KLEIN, S. L. 2004. Hormonal and immunological mechanisms mediating sex differences in parasite infection. Parasite Immunology 26:247-264.

KLukowski, M. 2004. Seasonal changes in abundance of host-seeking chiggers (Acari: Trombiculidae) and infestations on fence lizards, Sceloporus undulatus. Journal of Herpetology 38:141-144. 
Klukowski, M., and C. E. Nelson. 2001. Ectoparasite loads in free-ranging northern fence lizards, Sceloporus undulatus hyacinthinus: effects of testosterone and sex. Behavioral Ecology and Sociobiology 49: 289-295.

Kuo, M. M., R. S. Lane, and P. C. Giclas. 2000. A comparative study of mammalian and reptilian alternative pathway of complement-mediated killing of the Lyme disease spirochete (Borrelia burgdorferi). Journal of Parasitology 86:1223-1228.

Lane, R. S., And J. E. Loye. 1989. Lyme disease in California: interrelationship of Ixodes pacificus (Acari: Ixodidae), the western fence lizard (Sceloporus occidentalis), and Borrelia burgdorferi. Journal of Medical Entomology 26:272-278.

Lane, R. S., and J. E. Loye. 1991. Lyme disease in California: interrelationship of ixodid ticks (Acari), rodents, and Borrelia burgdorferi. Journal of Medical Entomology 28:719-725.

Lane, R. S., ANd G. B. Quistad. 1998. Borreliacidal factor in the blood of the western fence lizard (Sceloporus occidentalis). Journal of Parasitology 84:29-34.

Lane, R. S., J. E. Kleinjan, ANd G. B. Schoeler. 1995. Diel activity of nymphal Dermacentor occidentalis and Ixodes pacificus (Acari: Ixodidae) in relation to meteorological factors and host activity periods. Journal of Medical Entomology 32:290-299.

Lane, R. S., J. Mun, R. J. Eisen, and L. Eisen. 2005. Western gray squirrel (Rodentia: Sciuridae): a primary reservoir host of Borrelia burgdorferi in Californian oak-woodlands? Journal of Medical Entomology 42:388-396.

Madigan, J. E. 1993. Equine ehrlichiosis. Veterinary Clinics of North America: Equine Practices 9: 423-428.

Manweiler, S. A., R. S. Lane, and C. H. Tempelis. 1992. The western fence lizard Sceloporus occidentalis: evidence of field exposure to Borrelia burgdorferi in relation to infestation by Ixodes pacificus (Acari: Ixodidae). American Journal of Tropical Medicine and Hygiene 47:328-336.

Marler, K. A., G. Walsberg, M. White, and M. Moore. 1995. Increased energy expenditure due to increased territorial defense in male lizards after phenotypic manipulation. Behaviourial Ecology and Sociobiology 37:225-231.

Mougeot, F., S. M. Redpath, and S. B. Piertney. 2006. Elevated spring testosterone increases parasite intensity in male red grouse. Behavioral Ecology 17:127-135.

Olsson, M., E. Wapstra, T. Madsen, and B. Silverin. 2000. Testosterone, ticks and travels: a test of the immunocompetence-handicap hypothesis in freeranging male sand lizards. Proceedings of the Royal Society of London B, Biological Sciences 267: 2339-2343.

Oppliger, A., M. S. Giorgi, A. Conelli, M. Nembrini, And H. B. John-Alder. 2004. Effect of testosterone on immunocompetence, parasite load, and metabolism in the common wall lizard (Podarcis muralis). Canadian Journal of Zoology 82:1713-1719.

Padgett, K. A., And R. S. Lane. 2001. Life cycle of Ixodes pacificus (Acari: Ixodidae): timing of developmental processes under field and laboratory conditions. Journal of Medical Entomology 38: 684-693.

Peavey, C. A., R. S. Lane, and J. E. Kleinjan. 1997. Role of small mammals in the ecology of Borrelia burgdorferi in a peri-urban park in north coastal California. Experimental and Applied Acarology 21: 569-584.

Reubel, G. H., R. B. Kimsey, J. E. Barlough, and J. E. Madigan. 1998. Experimental transmission of Ehrlichia equi to horses through naturally infected ticks (Ixodes pacificus) from northern California. Journal of Clinical Microbiology 36:2131-2134.

Roberts, M. L., K. L. Buchanan, and M. R. Evans. 2004. Testing the immunocompetence handicap hypothesis: a review of the evidence. Animal Behaviour 68: 227-239.

Salvador, A., J. P. Veiga, J. Martin, P. Lopez, M. Abelenda, and M. Puerta. 1996. The cost of producing a sexual signal: testosterone increases the susceptibility of male lizards to ectoparasite infestation. Behavioral Ecology 7:145-150.

Schalk, G., ANd M. R. Forbes. 1997. Male biases in parasitism of mammals: effects of study type, host age, and parasite taxon. Oikos 78:67-74.

Schall, J. J., H. R. Prendeville, and K. Hanley. 2000. Prevalence of the tick, Ixodes pacificus, on western fence lizards, Sceloporus occidentalis: trends by site, gender, size, season, and mite infestation. Journal of Herpetology 34:160-163.

Slowik, T. J., AND R. S. Lane. 2001. Nymphs of the western black-legged tick (Ixodes pacificus) collected from tree trunks in woodland-grass habitat. Journal of Vector Ecology 26:165-171.

Tälleklint-Eisen, L., And R. J. Eisen. 1999. Abundance of ticks (Acari: Ixodidae) infesting the western fence lizard, Sceloporus occidentalis, in relation to environmental factors. Experimental and Applied Acarology 23:731-740.

Veiga, J. P., A. Salvador, S. Merino, and M. Puerta. 1998. Reproductive effort affects immune response and parasite infection in a lizard: a phenotypic manipulation using testosterone. Oikos 82:313-318.

Wedekind, C., and I. Folstad. 1994. Adaptive and nonadaptive immunosuppression by sex hormones. American Naturalist 143:936-938.

Wikel, S. K. 1996. Host immunity to ticks. Annual Review of Entomology 41:1-22.

Wright, S. A., R. S. Lane, and J. R. Clover. 1998. Infestation of the southern alligator lizard (Squamata: Anguidae) by Ixodes pacificus (Acari: Ixodidae) and its susceptibility to Borrelia burgdorferi. Journal of Medical Entomology 35:1044-1049. 
Yuval, B., And A. Spielman. 1990. Duration and regulation of the developmental cycle of Ixodes dammini (Acari: Ixodidae). Journal of Medical Entomology 27:196-201.

Zuk, M. 1990. Reproductive strategies and sex differences in disease susceptibility: an evolutionary viewpoint. Parasitology Today 6:231-233.
Zuk, M., and K. A. McKean. 1996. Sex differences in parasite infections: patterns and processes. International Journal of Parasitology 26:1009-1024.

Submitted 26 April 2010. Accepted 13 January 2011. Associate Editor was Rocky Ward. 